\title{
A Dutch geoscience perspective on the Katrina disaster
}

\section{T.E. Törnqvist}

Department of Earth and Environmental Sciences, Tulane University, 6823 St. Charles Avenue, New Orleans, Louisiana 70118-5698, USA.

Email: tor@tulane.edu

Manuscript received: February 2006; accepted: December 2006

\begin{abstract}
A combination of geological and anthropogenic processes have rendered the U.S. Gulf Coast in general - and the Mississippi Delta in particular extremely sensitive to coastal hazard. Thus, the Katrina disaster was not a question of 'if' but of 'when'. This contribution outlines the geoenvironmental context of the Mississippi Delta that evolved during the 20th century and set the stage for Hurricane Katrina's devastation. This includes a brief discussion of the processes responsible for coastal erosion and wetland loss, the proposed measures to combat these problems, and the policy decisions (or, rather, the lack thereof) made so far. A connection is made with the 1953 storm surge that devastated the southwestern Netherlands and had a profound impact on Dutch science and engineering by providing the impetus for the widely known and highly praised Delta Plan, as well as for unprecedented studies of Holocene sea-level change. Whether a similar route will be followed for the Gulf Coast is primarily dependent on the amount of political will. Results are presented of recent studies of crustal movements in the Mississippi Delta that show surprising long-term stability of the Pleistocene basement, evidence that could prove critical for decision makers with regard to the rebuilding process. Finally, the neglect of the precarious situation along the Gulf Coast by the federal government is viewed as a possible metaphor for current U.S. policies with respect to science in general, and to global warming in particular.
\end{abstract}

Keywords: Hurricane Katrina, wetland loss, subsidence, global change, Delta Plan, Mississippi Delta

"Land that sits below sea level. Levees and dams that stand against nature's fury. Countryside that sinks more every year. New Orleans? No. Holland: a nation whose flood protections makes ours look primitive and slapdash"

John McQuaid, The Times-Picayune, November 13, 2005

\section{Introduction}

Hurricane Katrina was by no means a surprise. In fact, scientists along the United States Gulf Coast had for decades predicted a disaster like the one that took place in late August of 2005 (Groat, 2005). The system of manmade levees that protected the New Orleans metropolitan area was designed to withstand a Category 3 hurricane (sustained wind speeds up to $209 \mathrm{~km} \mathrm{hr}^{-1}$ ). Being spared a major hit since Hurricane Betsy in 1965, a new strike was overdue, and it was clear that, sooner or later, such a strike could be of the stronger Category 4 or 5 . The inevitability of a hurricane disaster and associated deep flooding of vast urban areas had been spelled out at length in the news media in preceding years. A noteworthy example is the extensive, visionary report in The Times-Picayune (the leading New Orleans daily newspaper), published June 23 - 27, 2002, as a five-day series. This collection of articles received the Excellence in Journalism Award from the American Society of Civil Engineers in 2003.

Katrina made landfall in the early morning of August 29, 2005, near the birdfoot of the Mississippi Delta (Fig. 1) as a strong Category 3 hurricane. The eye of the storm followed a track just east of New Orleans before it made a second landfall near the Louisiana-Mississippi border. Apart from causing wind damage, the counterclockwise circulation pumped water from the Gulf of Mexico into Lake Pontchartrain. Northerly 


\title{
A Dutch geoscience perspective on the Katrina disaster
}

\section{T.E. Törnqvist}

Department of Earth and Environmental Sciences, Tulane University, 6823 St. Charles Avenue, New Orleans, Louisiana 70118-5698, USA.

Email: tor@tulane.edu

Manuscript received: February 2006; accepted: December 2006

\begin{abstract}
A combination of geological and anthropogenic processes have rendered the U.S. Gulf Coast in general - and the Mississippi Delta in particular extremely sensitive to coastal hazard. Thus, the Katrina disaster was not a question of 'if' but of 'when'. This contribution outlines the geoenvironmental context of the Mississippi Delta that evolved during the 20th century and set the stage for Hurricane Katrina's devastation. This includes a brief discussion of the processes responsible for coastal erosion and wetland loss, the proposed measures to combat these problems, and the policy decisions (or, rather, the lack thereof) made so far. A connection is made with the 1953 storm surge that devastated the southwestern Netherlands and had a profound impact on Dutch science and engineering by providing the impetus for the widely known and highly praised Delta Plan, as well as for unprecedented studies of Holocene sea-level change. Whether a similar route will be followed for the Gulf Coast is primarily dependent on the amount of political will. Results are presented of recent studies of crustal movements in the Mississippi Delta that show surprising long-term stability of the Pleistocene basement, evidence that could prove critical for decision makers with regard to the rebuilding process. Finally, the neglect of the precarious situation along the Gulf Coast by the federal government is viewed as a possible metaphor for current U.S. policies with respect to science in general, and to global warming in particular.
\end{abstract}

Keywords: Hurricane Katrina, wetland loss, subsidence, global change, Delta Plan, Mississippi Delta

"Land that sits below sea level. Levees and dams that stand against nature's fury. Countryside that sinks more every year. New Orleans? No. Holland: a nation whose flood protections makes ours look primitive and slapdash"

John McQuaid, The Times-Picayune, November 13, 2005

\section{Introduction}

Hurricane Katrina was by no means a surprise. In fact, scientists along the United States Gulf Coast had for decades predicted a disaster like the one that took place in late August of 2005 (Groat, 2005). The system of manmade levees that protected the New Orleans metropolitan area was designed to withstand a Category 3 hurricane (sustained wind speeds up to $209 \mathrm{~km} \mathrm{hr}^{-1}$ ). Being spared a major hit since Hurricane Betsy in 1965, a new strike was overdue, and it was clear that, sooner or later, such a strike could be of the stronger Category 4 or 5 . The inevitability of a hurricane disaster and associated deep flooding of vast urban areas had been spelled out at length in the news media in preceding years. A noteworthy example is the extensive, visionary report in The Times-Picayune (the leading New Orleans daily newspaper), published June 23 - 27, 2002, as a five-day series. This collection of articles received the Excellence in Journalism Award from the American Society of Civil Engineers in 2003.

Katrina made landfall in the early morning of August 29, 2005, near the birdfoot of the Mississippi Delta (Fig. 1) as a strong Category 3 hurricane. The eye of the storm followed a track just east of New Orleans before it made a second landfall near the Louisiana-Mississippi border. Apart from causing wind damage, the counterclockwise circulation pumped water from the Gulf of Mexico into Lake Pontchartrain. Northerly 

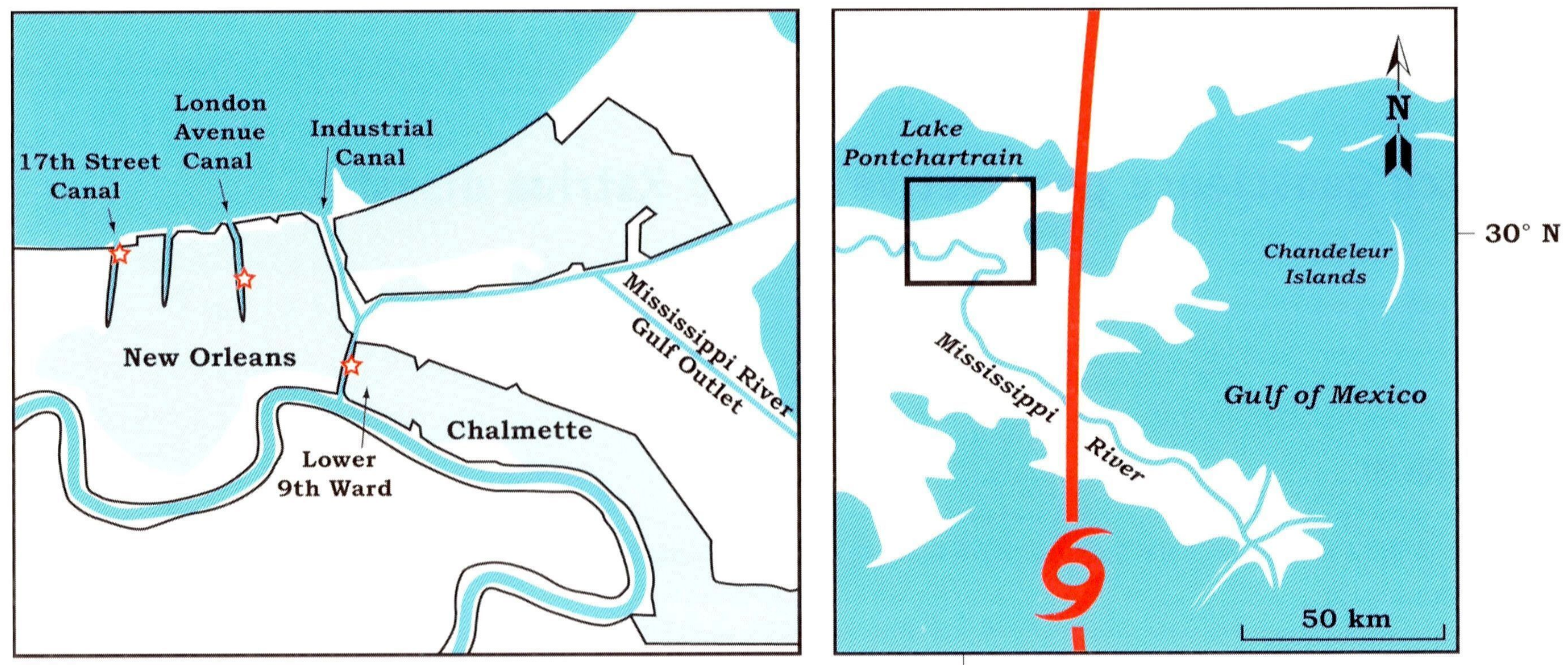

$90^{\circ} \mathrm{W}$

Fig. 1. Map of the New Orleans area (left) with topographic features mentioned in text. Levees are shown in black and the maximum extent of flooding is indicated in light blue. Levee breaches discussed in the text are shown by red stars. Overview map (right) shows the track of the eye of Hurricane Katrina. Note the open connection between Lake Pontchartrain and the Gulf of Mexico.

winds subsequently pushed the storm surge towards the levees along its southern shores and into the heart of the city through drainage canals that were in open connection with the lake. At the same time, shipping canals (notably the Mississippi River Gulf Outlet) provided a conduit for the storm surge to enter New Orleans from the southeast (Fig. 1). Thus, the stage was set for a series of levee breaches along drainage canals plus extensive overtopping of levees, mainly along Lake Pontchartrain and the Mississippi River Gulf Outlet, with devastating consequences (Figs 2 - 5). Although Hurricane Katrina was strictly a natural disaster, it had a strong anthropogenic imprint. In fact, Katrina can be seen to a large extent as a human disaster, the character of which is threefold: 1) long-term neglect of the vitality of the natural coastal-defense system consisting of extensive wetlands and barrier-island chains; 2) a variety of failures in the design and execution of the engineered coastal-defense system; and 3) the completely inadequate emergency response immediately after the storm.

Estimates of the monetary damage due to Hurricane Katrina are still in a state of flux, but will almost certainly be in the neighborhood of $\$ 100$ billion or more, making it by far the costliest natural disaster in U.S. history. Why the federal government chose to ignore the severe threat to such an economically and culturally vital area will likely be a topic of study for historians for a long time to come. The present contribution discusses the Katrina disaster in a geoscience context and puts the current situation along the U.S. Gulf Coast in the historical perspective of the 1953 storm surge that flooded much of the southwestern Netherlands.

\section{Geo-environmental context}

Accelerated sea-level rise due to greenhouse warming is likely to become one of Earth's premier environmental problems in the 21st century. The most recent Intergovernmental Panel on Climate Change (IPCC) report predicts a rise of global average sea level between 1980 - 1999 and 2090 - 2099 of 18 to $59 \mathrm{~cm}$ (Meehl et al., 2007), although it is stressed that these modelbased predictions do not adequately consider ice-sheet dynamics (and, hence, may be overly optimistic). Coastal lowlands can therefore expect major challenges during that period, not in the least due to the rapid growth of the world's population in the coastal zone. Particularly in deltaic settings, where land subsidence rates tend to be relatively high, problems due to relative sea-level (RSL) rise are potentially severe.

Like many of the world's deltas, the Mississippi Delta has degraded considerably due to human action, primarily after the catastrophic river flood of 1927 that triggered major engineering works in the 1930s. The drastic improvement of the levee system along the Mississippi and Atchafalaya Rivers protected most of the delta plain from flooding, but also deprived it from the influx of sediment (Fig. 6). As a consequence, a delicate balance that had existed for several millennia was suddenly disrupted, and the unrelenting subsidence of the land surface (exacerbated by artificial drainage and subsurface fluid withdrawal) was no longer offset by rapid sedimentation rates. This has resulted in extremely high rates of drowning of coastal wetlands (mainly salt marshes), along with accelerated erosion of barrier islands (e.g., Penland \& Suter, 1988; Day \& Templet, 1989). In addition, direct human impacts like the dredging of canals for the oil and gas industry have led to salt 

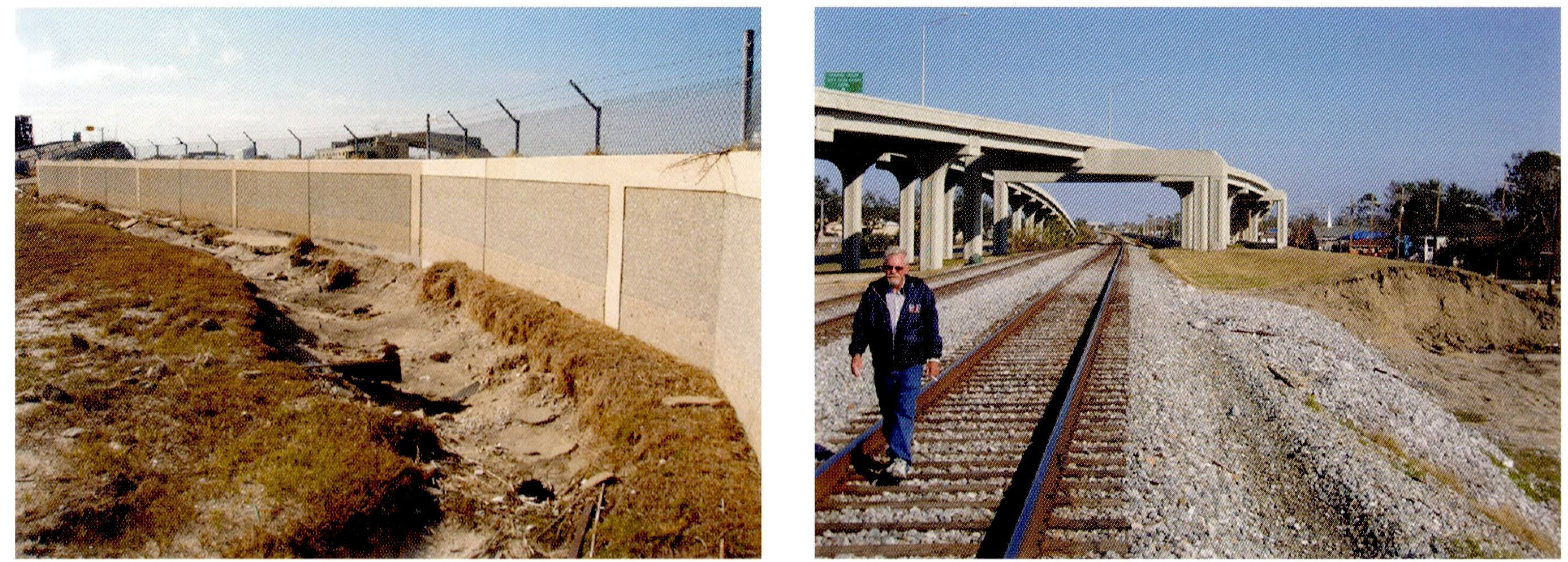

a.

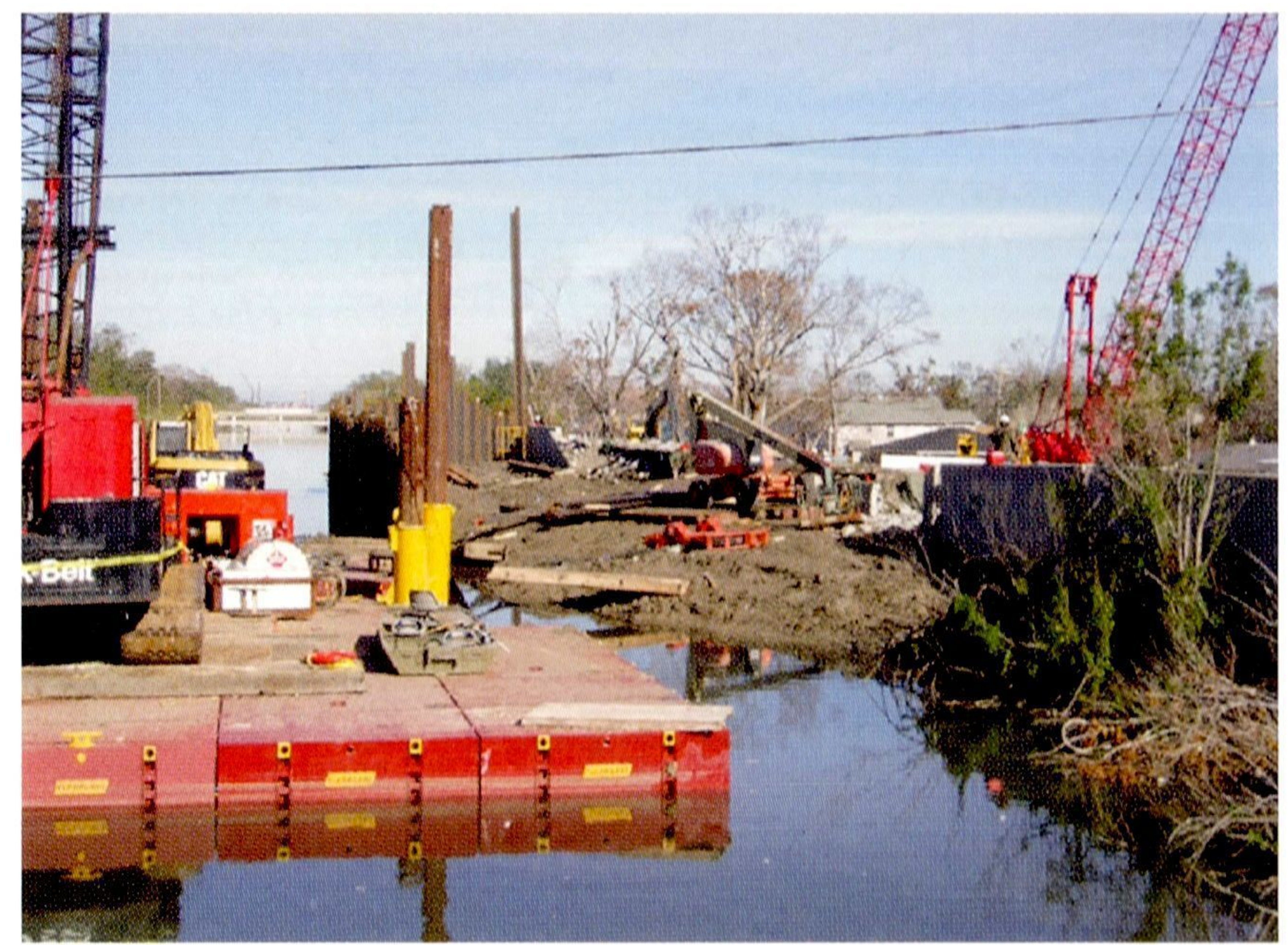

b.

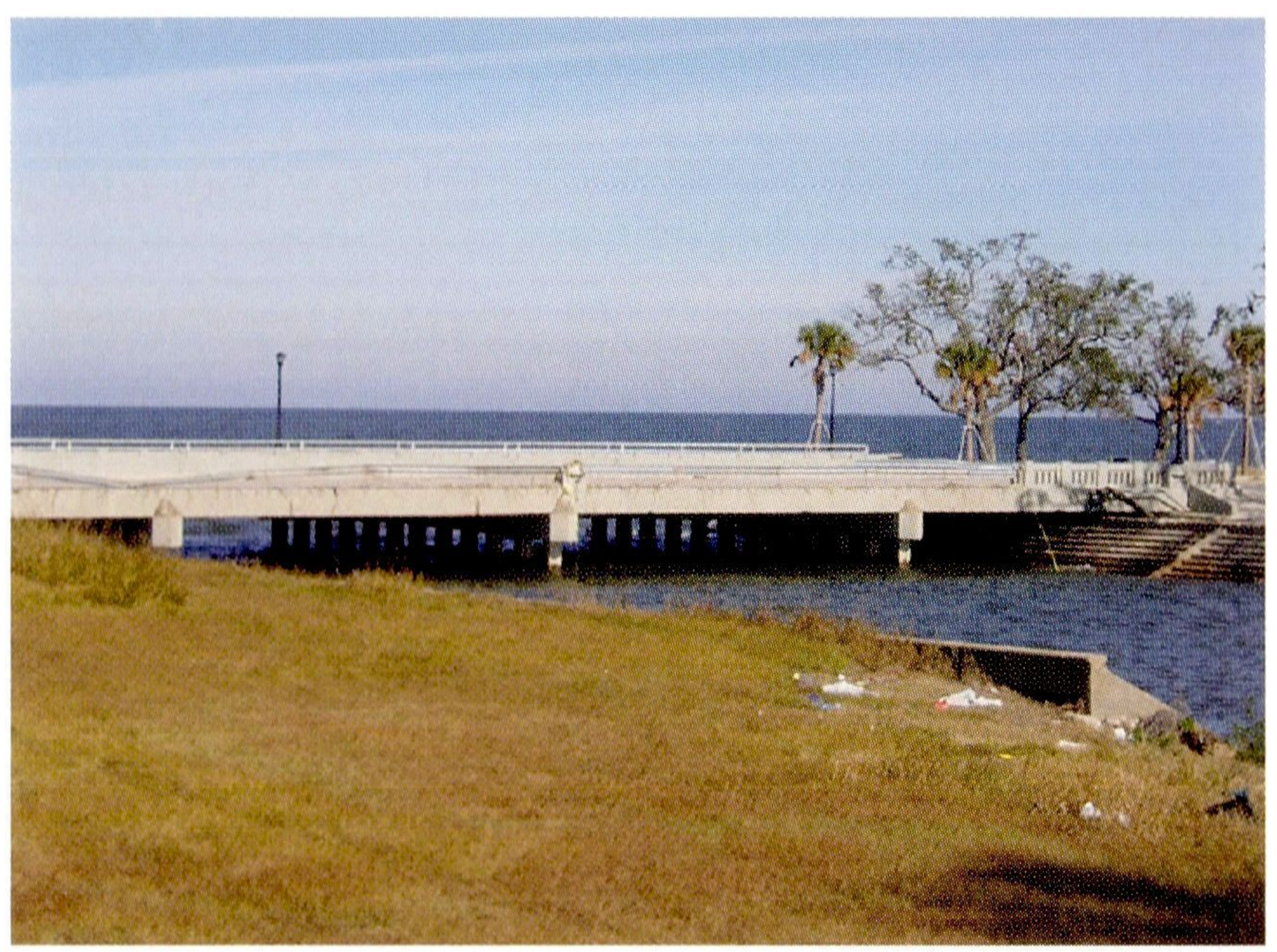

d.

Fig. 2. Hurricane Katrina's impact on the coastal-defense system in New Orleans. a. Evidence for overtopping by waves of a concrete floodwall on the crest of a levee along Lake Pontchartrain. Note the eroded trench and initial undermining of the floodwall. b. A railroad intersects the levee along Lake Pontchartrain (the lake is located to the left), providing a topographic low that was overtopped by the storm surge and resulted in severe erosion of the levee (far right). c. Provisional reparation of the breach on the eastern side of the London Avenue Canal. d. Mouth of the London Avenue Canal at Lake Pontchartrain. Note the open connection between the canal and the lake, allowing flood waters to penetrate into the heart of the city. Photos taken in December 2005.

intrusion, effectively killing large tracts of swamp forests. Rates of wetland loss increased to $50-100 \mathrm{~km}^{2} \mathrm{yr}^{-1}$ in the course of the last century (Gagliano et al., 1981; Britsch \& Dunbar, 1993) and current losses have been estimated at rates as high as one acre per 24 minutes (Fischetti, 2001).

Coastal wetlands belong to the most valuable natural ecosystems from an economic perspective, with a total value estimated at $\$ 10,000$ to $\$ 20,000 \mathrm{ha}^{-1} \mathrm{yr}^{-1}$ (Costanza et al., 1997). The ecological services provided by coastal wetlands are highly diverse, with protection against storm surge as a prominent asset. Coastal Louisiana accounts for about $80 \%$ of the wetland loss of the conterminous United States.

There have been increasing efforts, particularly at the state level, to monitor, understand, and predict coastal-wetland loss, as well as to propose remedies. Perhaps the best known initiative is the Coast 2050 Plan (Louisiana Coastal Wetlands Conservation and Restoration Task Force and the Wetlands Conservation and Restoration Authority, 1998; Reed \& Wilson, 2004) that puts forward a comprehensive set of measures to arrest the rapid deterioration of coastal Louisiana. This plan involves a broad spectrum of coastal restoration projects, primarily consisting of numerous diversions from the Mississippi River to bring sediment back into the rapidly degrading wetland areas. One of the most notable components is the proposed creation of a semi-natural distributrary parallel to Bayou Lafourche in the Barataria Basin (Fig. 6) that would attract 5\% of the Mississippi River discharge. Current thinking on coastal restoration is summarized by Day et al. (2007).

The coastal restoration projects outlined in the Coast 2050 Plan, along with a variety of hard engineering structures, would not be cheap. This proposal resulted in a $\$ 14$ billion request for federal support to counter the potentially devastating 

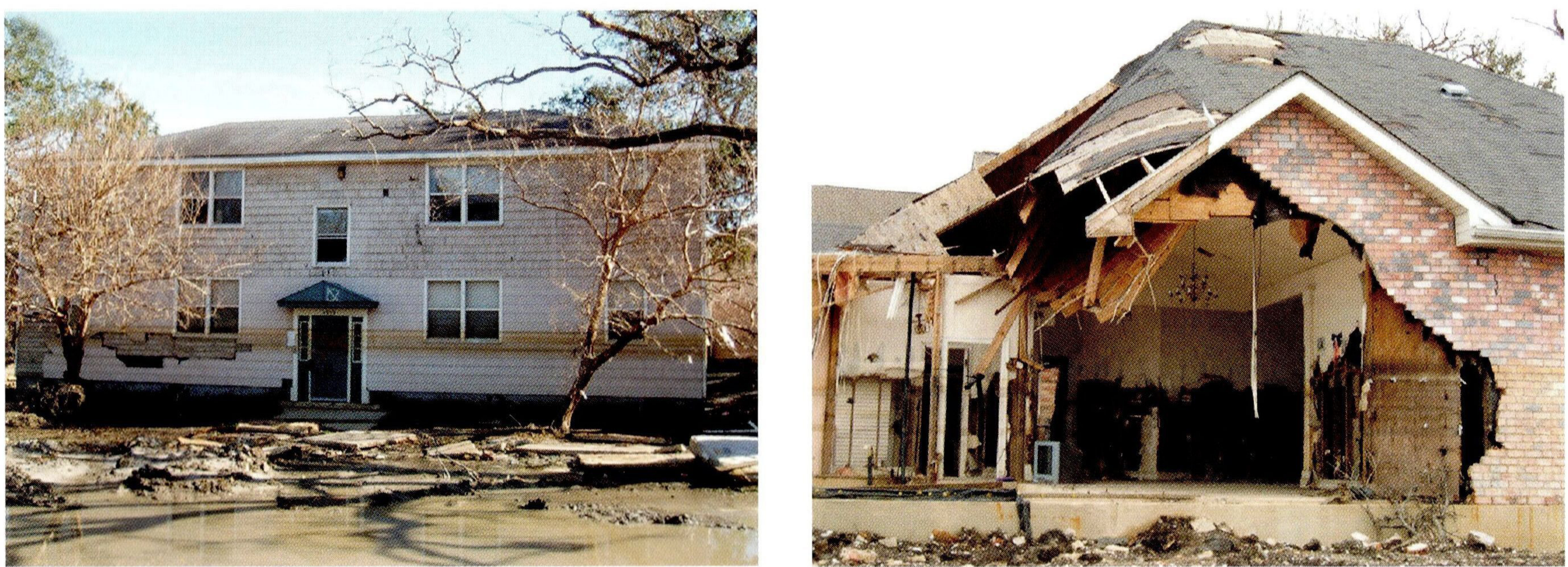

a.

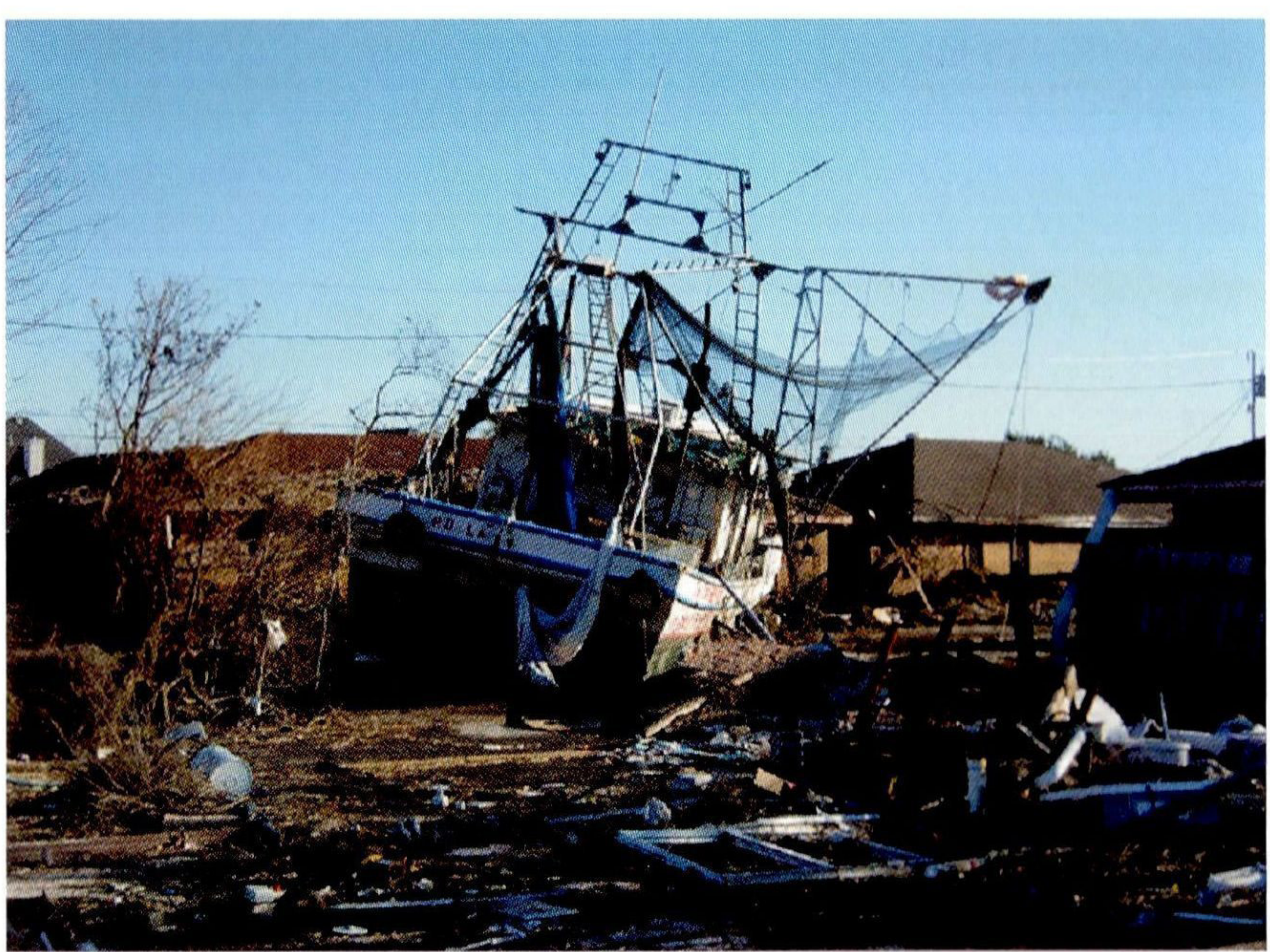

b.

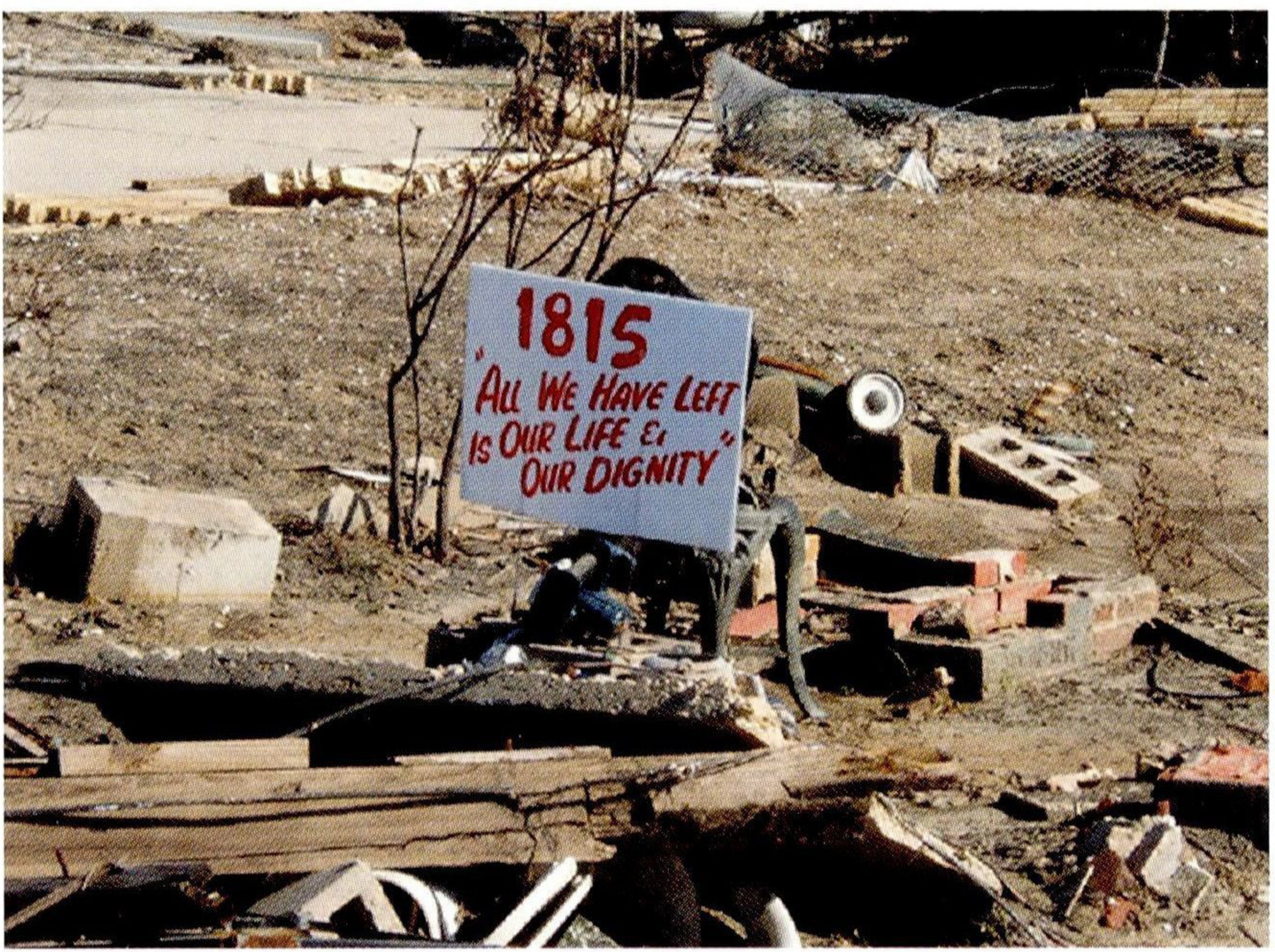

Fig. 3. Flood damage in the New Orleans metropolitan area. a. A conspicuous flood mark on a building near the London Avenue Canal. Related phenomena can be observed throughout the flooded areas. In this case, maximum flooding was about $0.5 \mathrm{~m}$ deeper, representing the short time interval when water levels in Lake Pontchartrain had not yet equilibrated with sea level. b. Severely damaged home near the 17th Street Canal levee breach site. c. Shrimp fishing boat in a devastated residential neighborhood in Chalmette. $d$. Makeshift house sign in the eradicated area near the main levee breach along the Industrial Canal in the Lower 9th Ward. Photos taken in December 2005.

consequences of continued deterioration of coastal Louisiana (Bourne, 2000). The unparalleled cost for a program that now, ironically, pales in the post-Katrina world, is likely the premier reason that it has not come to fruition. Although Coast 2050 has enjoyed wide support from scientists, engineers, and policymakers in Louisiana, it may not be free of caveats and much work remains to be done in order to increase our understanding of the extent to which coastal wetlands and barrier islands can suppress storm surge.

While there is widespread consensus that the rapid loss of coastal wetlands is intimately related to high subsidence rates of the land surface, the driving forces behind the subsidence process are still incompletely understood. Subsidence involves a wide variety of natural and anthropogenic factors, but their relative importance is not well constrained and poorly quantified.

\section{A Dutch connection}

The 1953 storm surge in the southwestern Netherlands triggered a vigorous government response. Drastic improvement of the coastal-defense system became a national priority, culminating in the Delta Plan that was largely completed in the mid-1980s with the construction of the 0osterscheldedam that now serves as a model for low-lying coastal areas worldwide (a recent review of the subject is provided by Gerritsen, 2005). The 1953 flood also reshaped the geoscience research agenda in the Netherlands, stimulating a variety of coastal investigations as exemplified by the classical sea-level study by Jelgersma (1961) that still stands out as a landmark contribution. Her work was underpinned by more than $100{ }^{14} \mathrm{C}$ ages, an unprecedented investment in those early days of radiocarbon dating. As will be shown below, the study by Jelgersma 


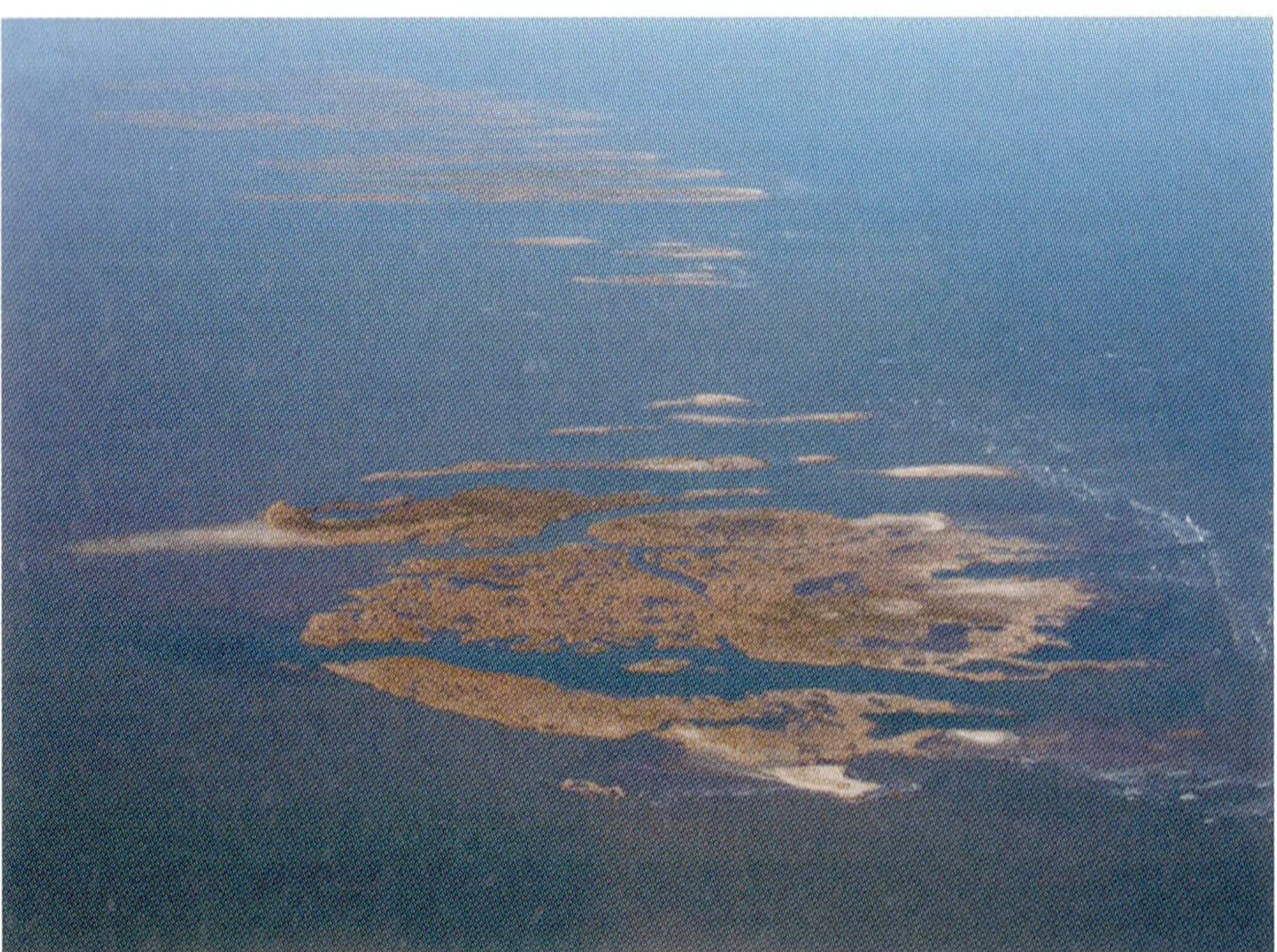

a.

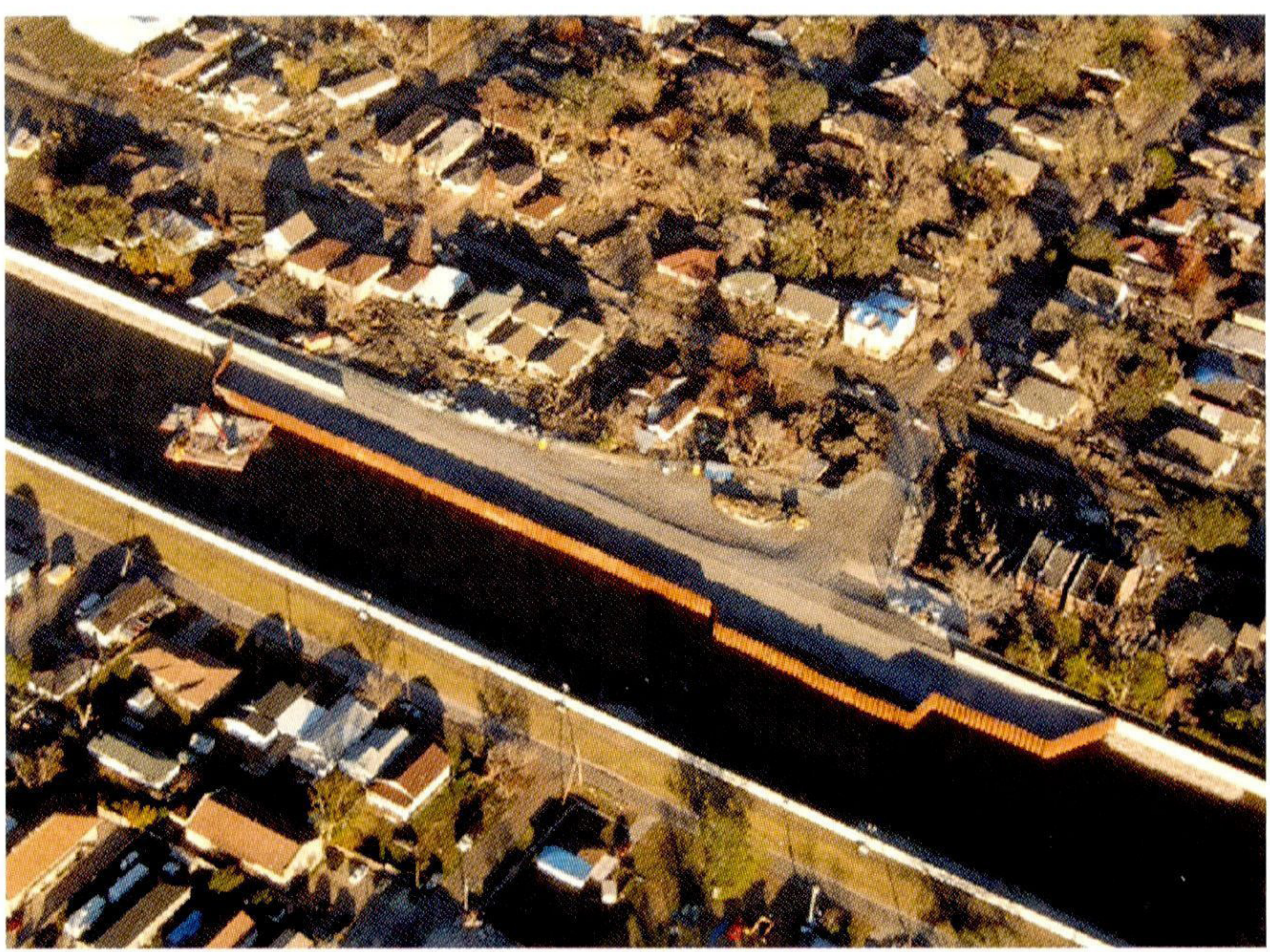

Fig. 4. Aerial photos showing Katrina's destruction. a. View towards the north of the Chandeleur Islands that were heavily breached by Katrina's storm surge. Note the large gap between the remaining land in the foreground and the fragments in the distance, unlikely to fully recover by means of fairweather wave action. b. Detailed view of the dissection of the core of the Chandeleur Islands. c. Provisional reparation of the levee breach at the 17 th Street Canal. $d$. The extent of the destruction around the main breach in the levee of the Industrial Canal, viewed towards the Lower 9 th Ward. The only remaining features near the breach site are the rectangular, concrete slabs that serve as the foundation for most homes. More information on the causes of levee breaches can be found in Seed et al. (2006) and Van Heerden \& Bryan (2006). Photos taken in December 2005.

(1961) constitutes the methodological foundation for recent and ongoing research in the Mississippi Delta.

The current level of protection of the major cities in the Netherlands is such that the coastal-defense system can withstand 10,000-year floods (Vrijling, 2001). This provides a stark contrast with the 200-year floods for which U.S. levees are typically designed, although one could argue that the levee system in New Orleans was not up to this standard (Jonkman et al., 2005; Van Heerden \& Bryan, 2006). While on one hand the Katrina disaster has led to renewed concern about the integrity of the Dutch coastal-defense system, there is an increasing interest to explore unconventional, adaptive strategies to cope with future climate and sea-level change (Kabat et al., 2005). Such new developments testify to the continued Dutch commitment to scrutinize its vulnerable environmental setting in the context of an uncertain future.

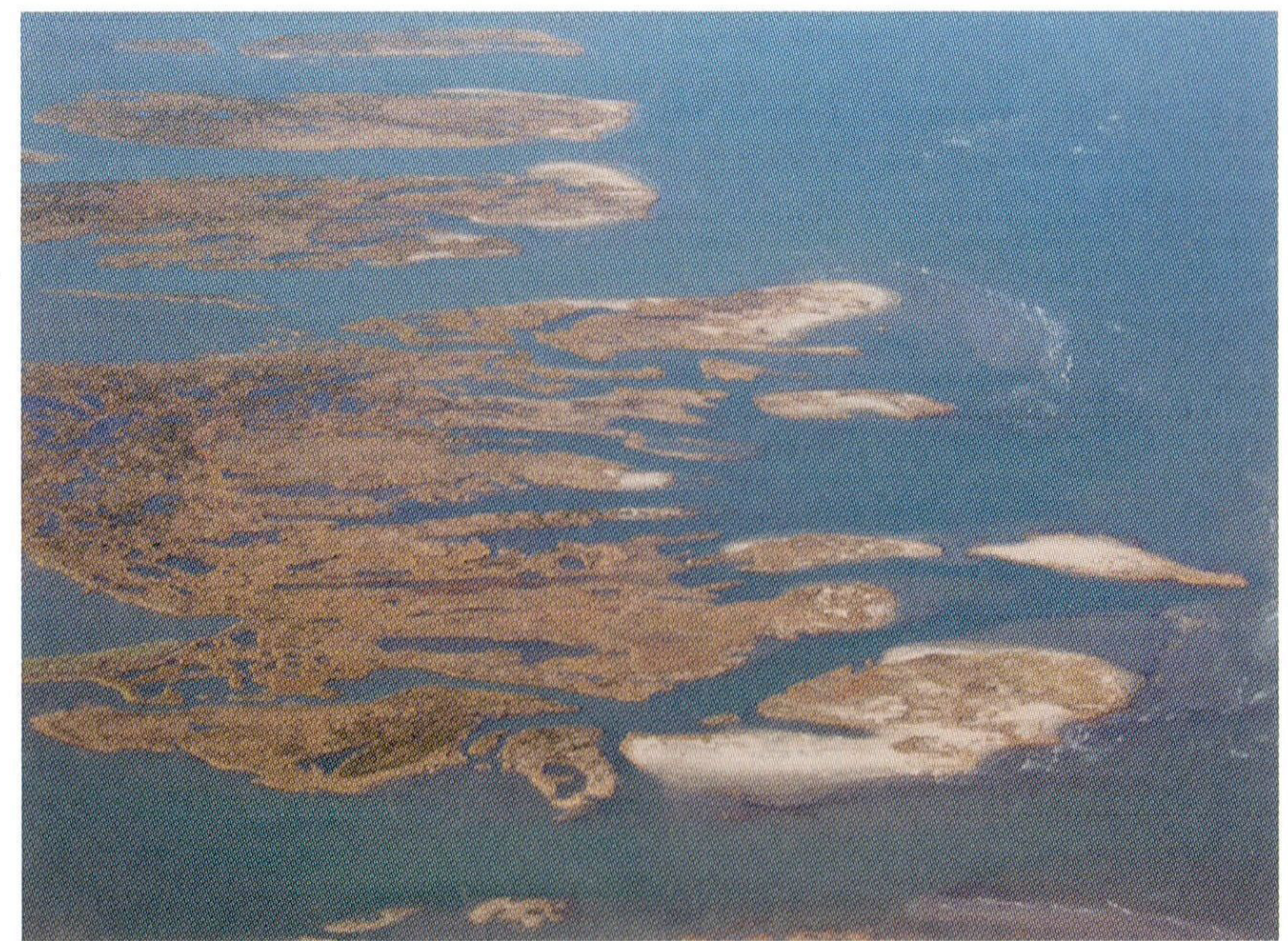

b.

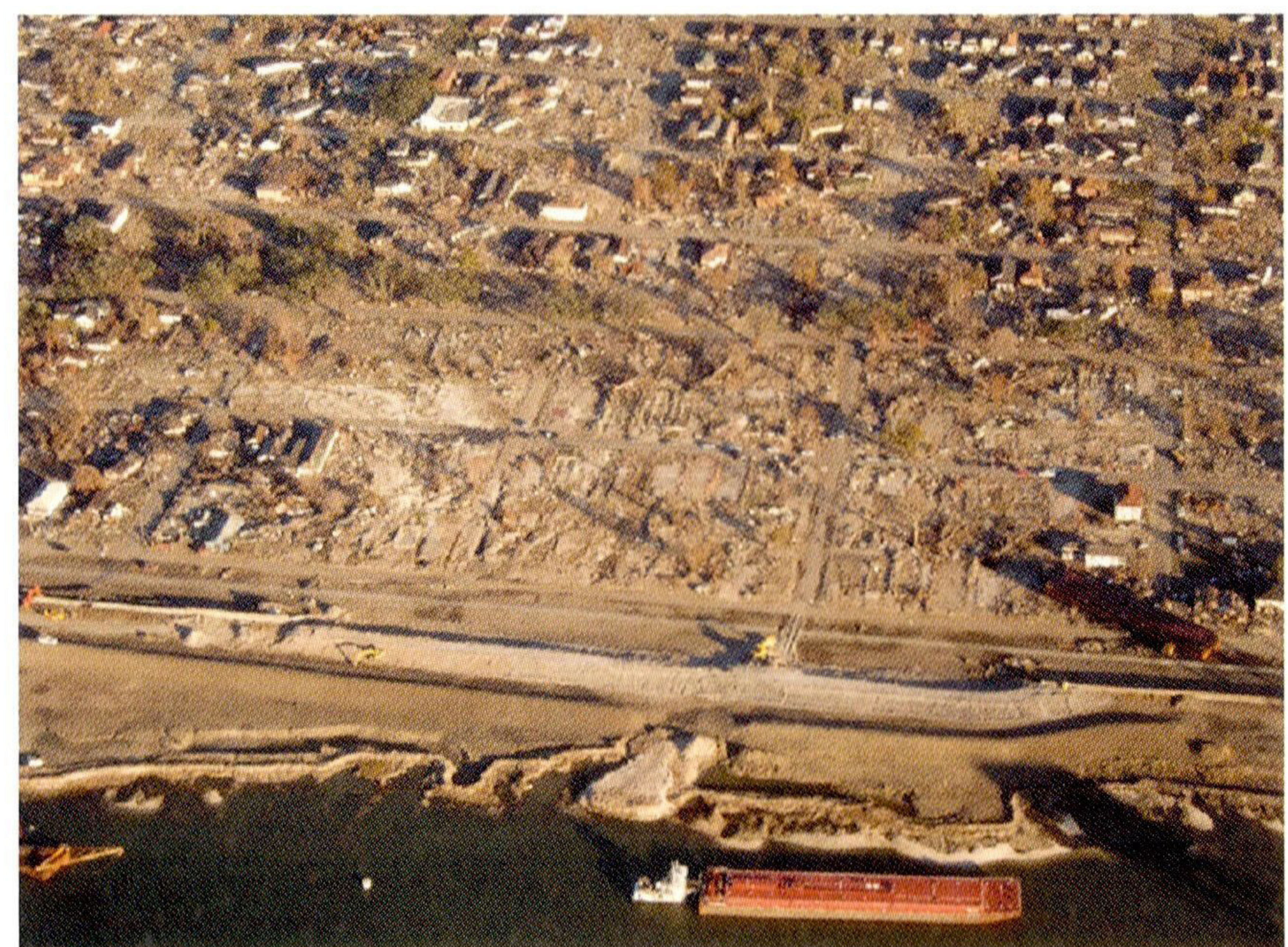

d. 


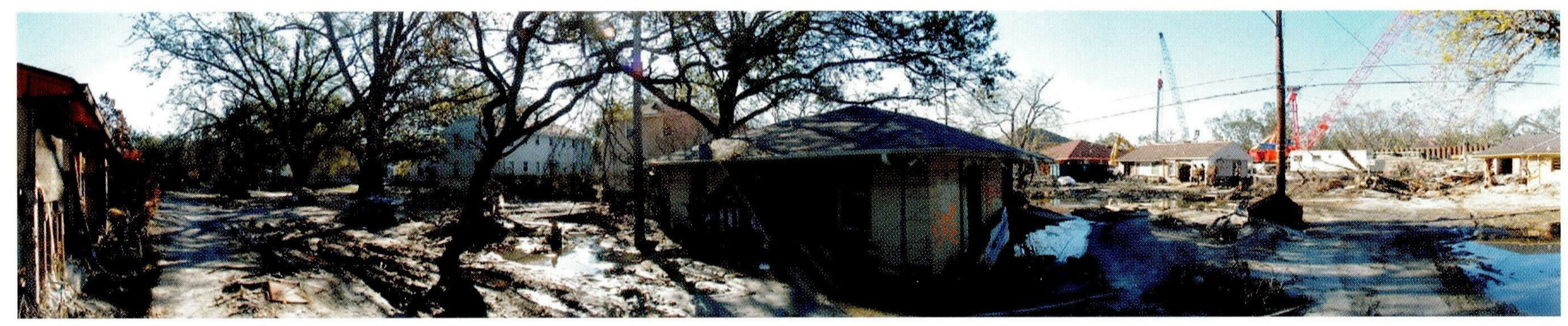

a.

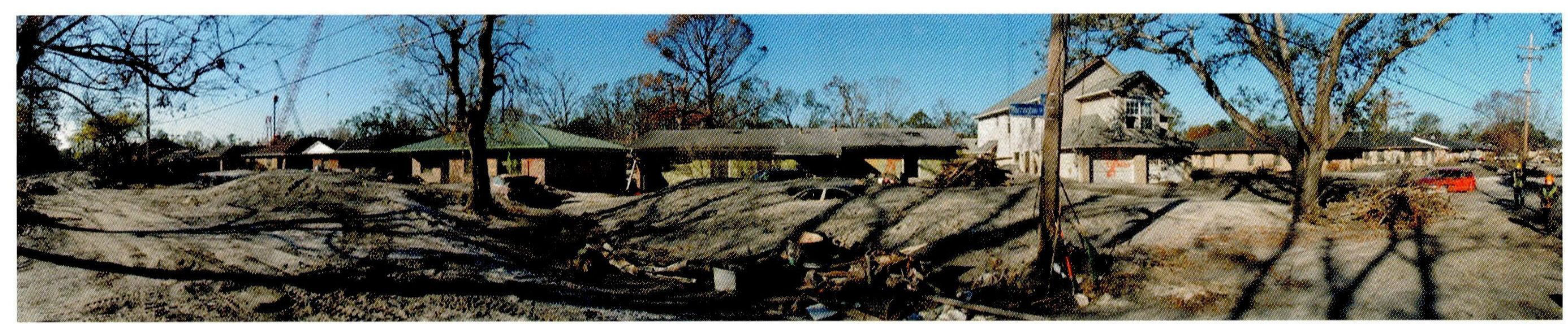

b.

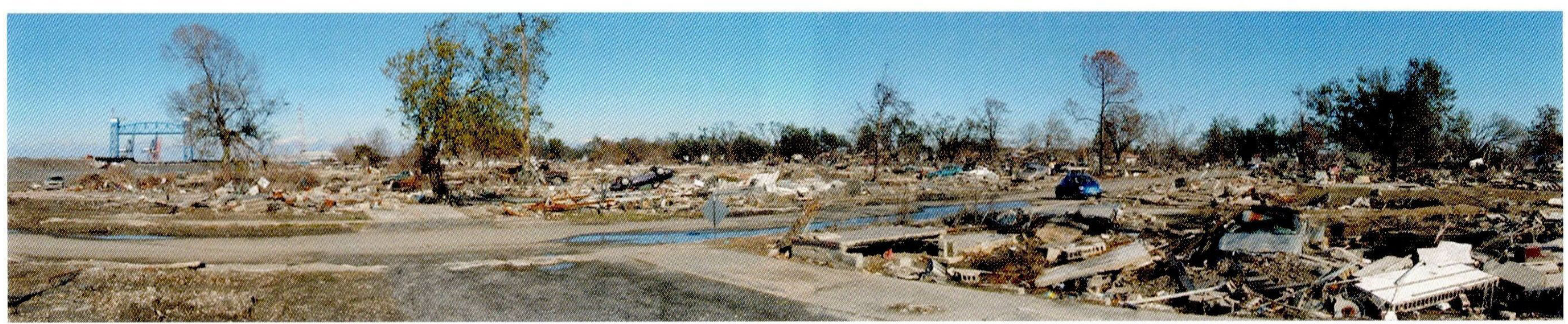

c.

Fig. 5. Near- $180^{\circ}$ panoramic views in the immediate vicinity of breached levee sites in New Orleans. a. London Avenue Canal, with cranes on the righthand side indicating location of the breach where reparations are ongoing (see Fig. 2c). The open lot in front of the red crane was the location of the home that is in the centre of the panorama and was displaced $\sim 40 \mathrm{~m}$ by the flood. Sediment-covered street on the lefthand side is oriented perpendicular to the canal. b. Outwash fan near the London Avenue Canal breach site with cranes on the lefthand side indicating location of the breach. The outwash fan consists predominantly of sands derived from the Pine Island barrier, a sand body that extends up to $10 \mathrm{~m}$ below the surface (Saucier, 1963). Thickness of the fan is in places $1.5 \mathrm{~m}$ or more, sufficient to bury cars. Note the largest fan thicknesses in the wake of the remaining homes, separated by channel-like depressions between buildings (a more detailed discussion of this deposit is provided by Nelson \& Leclair, 2006). Also note that roofs are nearly intact, testifying to the limited amount of wind damage compared to flood damage. c. Main breach in the Industrial Canal viewed from the Lower 9th Ward. The levee on the lefthand side has been almost completely restored. This area was built up with dense homes that were entirely eradicated. Note the nearly bare terrain near the breach site, giving way to piles of debris and overturned cars to the right. The radius of the area of complete destruction is at least $400 \mathrm{~m}$. Photos taken in December 2005.

Pleistocene basement that commonly serves as the foundation for major infrastructure. Recent sea-level studies in the Mississippi Delta (Törnqvist et al., 2002, 2004, 2006; González \& Törnqvist, 2006) have relied on the use of basal peat as a sea-level indicator, an approach heavily inspired by early Dutch work (e.g., Jelgersma, 1961; Van de Plassche, 1982). These recent studies take advantage of new geodetic technology (notably the differential Global Positioning System) and ${ }^{14} \mathrm{C}$ dating by accelerator mass spectrometry along with the use of $\delta^{13} \mathrm{C}$ data to infer paleosalinities so as to tie sea-level indicators to tide levels.

One key objective of these investigations is to quantify differential crustal movements and to unravel the relative contributions of eustasy, isostasy, and tectonism to late
Holocene RSL change. We predicted previously (Törnqvist et al., 2002) that the rate of RSL rise in the eastern Mississippi Delta during the past few millennia (the 'background' rate on which future, accelerated eustatic sea-level rise should be superimposed) was $0.5-0.6 \mathrm{~mm} \mathrm{yr}^{-1}$. Our latest results enable a first attempt to isolate the different components of RSL rise. A considerable role can likely be attributed to glacio-isostatic adjustment. Geophysical modeling (Peltier, 1998; Mitrovica \& Milne, 2002) estimates glacio-isostatic forebulge collapse of at least $\sim 0.5 \mathrm{~mm} \mathrm{yr}^{-1}$ for the central U.S. Gulf Coast, and Milne et al. (2005) have advocated that forebulge collapse associated with the melting of the Laurentide Ice Sheet may have extended as far south as northernmost South America. Recent data (Törnqvist et al., 2006) show that RSL records from 


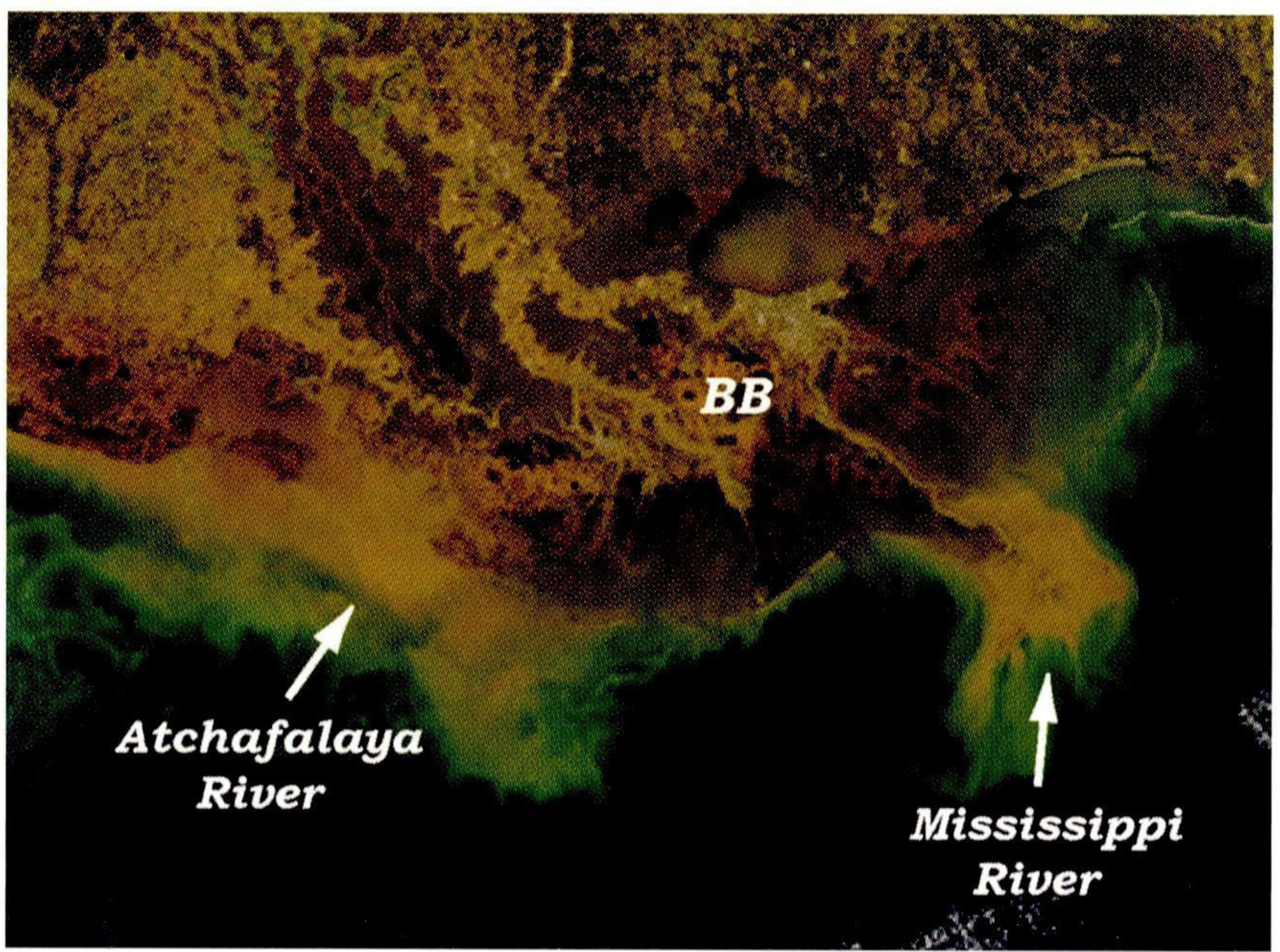

Fig. 6. Satellite image of the Mississippi Delta (January 2004) showing the sediment plumes at the birdfoot and the Atchafalaya. Outside of small portions of the deltaic plain in the vicinity of these sediment sources, coastal wetlands disappear at alarming rates. Wetland loss is particularly severe in the central part of the deltaic plain. Note the integrity of the Chandeleur Island Arc compared to the post-Katrina conditions (Figs $4 a$ and b). BB = Barataria Basin. Image courtesy Liam Gumley, Space Science and Engineering Center, University of WisconsinMadison.

different sections of the Mississippi Delta (Fig. 7) exhibit virtually similar RSL histories for the past $~ 8000$ years as tectonically stable areas in the Caribbean (Toscano \& Macintyre, 2003). This suggests that the combined contribution of lithospheric flexure due to sediment loading and long-term, thermal passive margin subsidence (referred to collectively here as tectonic subsidence) are of an order of magnitude of $0.1 \mathrm{~mm} \mathrm{yr}^{-1}$ only. It should be noted that these rates are unlikely to apply everywhere in the delta, and as discussed in more detail by Törnqvist et al. (2006) subsidence rates are much higher near the birdfoot delta. Our recent findings suggest a similar flexure pattern as was inferred by Fisk \& McFarlan (1955) and it is strikingly similar to observations by Stanley \& Warne (1993) from the Nile Delta.

Most recently, González \& Törnqvist (2006) have confirmed the preceding studies, using tens of sea-level index points from the western Mississippi Delta for the past 1500 years that show a long-term trend of RSL rise of $0.55 \mathrm{~mm} \mathrm{yr}^{-1}$. If the geophysical model predictions discussed above are correct (and ignoring the likely minor role of hydro-isostasy), the implication would be that the eustatic contribution to RSL rise during the late Holocene has been negligible, possibly even negative (cf. Lambeck et al., 2004). Obviously, this trend has been reversed drastically since pre-industrial times (Donnelly et al., 2004; Gehrels et al., 2005; González \& Törnqvist, 2006).

Clearly, the missing link in the current data set (Fig. 7) is evidence that pertains directly to the New Orleans metropolitan area, where the land surface is currently subsiding at rates of at least several $\mathrm{mm} \mathrm{yr}^{-1}$ (Dixon et al., 2006). Nevertheless, with the present state of knowledge there is reason to believe that the Pleistocene basement in this area may be more stable than commonly believed. Holocene RSL evidence could potentially play an important role in predicting the future of the Mississippi Delta and the adjacent Gulf Coast, and could underpin urban and land-use planning. For example, a relatively stable Pleistocene basement could provide a foundation for a broad range of infrastructure including housing, even with a land surface that continues to subside more rapidly.

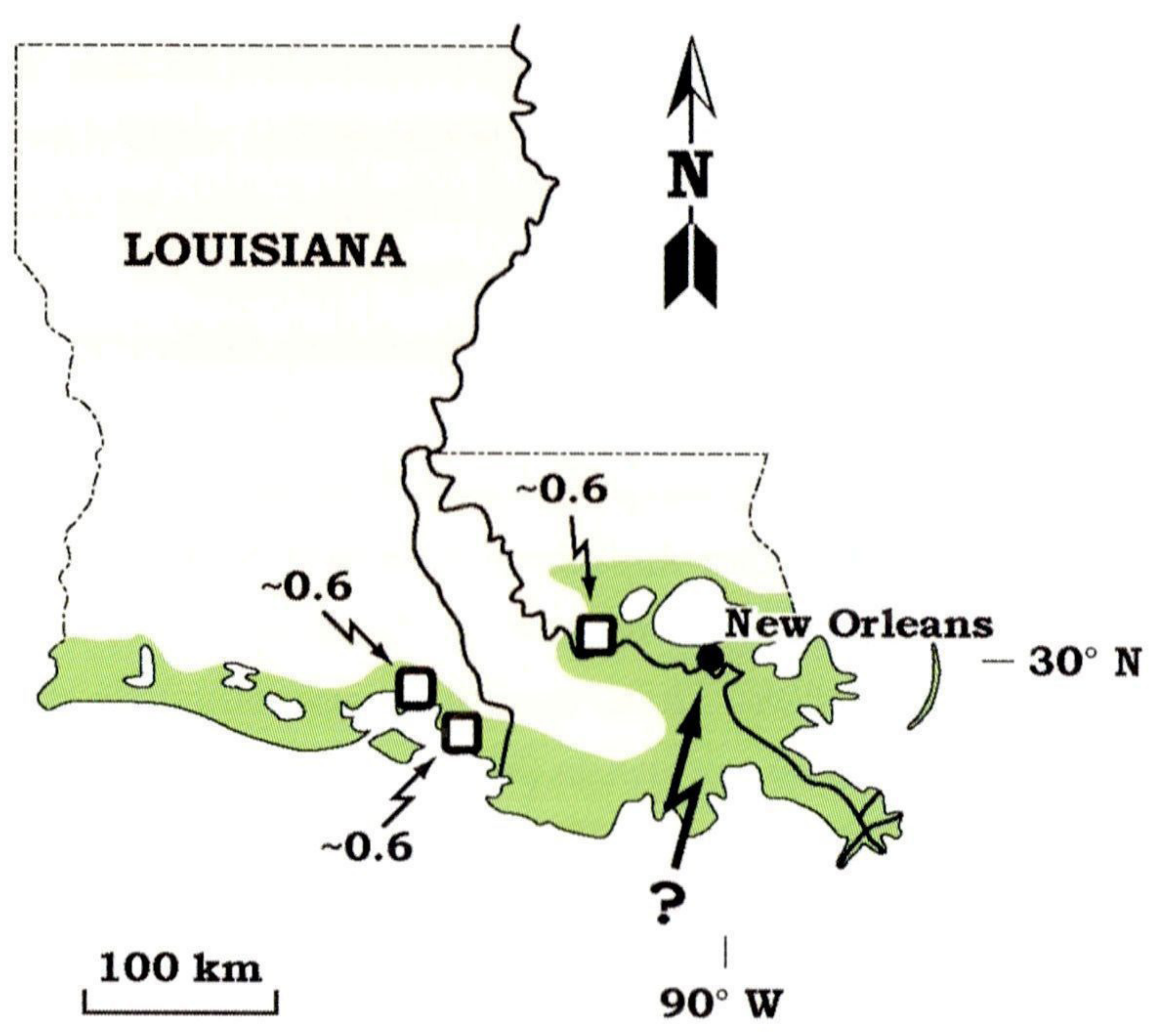

Fig. 7. Map with areas experiencing coastal wetland loss in green (after Van Beek and Meyer-Arendt, 1982). The study areas analyzed so far are indicated with approximate rates of subsidence of the Pleistocene base-

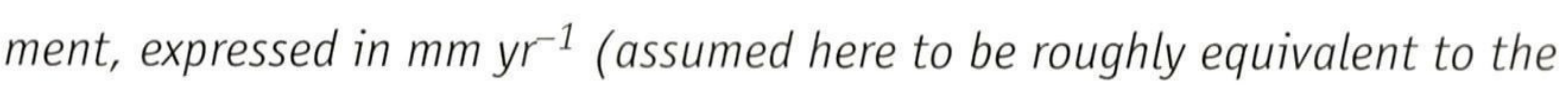
rate of late Holocene relative sea-level rise), after Törnqvist et al. (2002, 2004, 2006) and González \& Törnqvist (2006). Although no such data are currently available from the New Orleans metropolitan area, it appears likely that subsidence rates there are roughly of the same order of magnitude.

\section{Katrina, global change and the Koster legacy}

As a geomorphologist, Eduard A. Koster developed a strong interest in the problem of landscape response to global warming. With the benefit of hindsight it is now clear that he entered this game at an early stage. Apart from direct involvement in research (e.g., Boer et al., 1990; Koster, 1991; Koster \& Nieuwenhuijzen, 1992), he played a significant role as a driving force behind several workshops on this subject that were held in the late 1980s. Thus, he established himself as an early leader in a field that now involves thousands of scientists worldwide (e.g., Parry et al., 2007). While Koster's initial interests were centered on high-latitude (notably periglacial) settings, he was quick to recognize the vulnerability of lowland fluvial environments to global change. During subsequent years, he focused a large part of his efforts on establishing coordinated research programs in the Netherlands, with the principal aim 
to understand the functioning of fluvial systems in the context of future global change. There are striking connections between Ward Koster's interests in the geo-ecological impacts of climate change and the precarious situation along the U.S. Gulf Coast. of particularly critical importance for the Gulf Coast is an improved capability to predict future, climate-related sealevel change and its impact on landscape dynamics.

While the overall ignorance of the vulnerability of the Gulf Coast has been a hallmark of federal U.S. politics for decades, the situation has deteriorated significantly in recent years. The George W. Bush administration has developed a questionable record with respect to science policy in general (Mooney, 2005) and climate change in particular (King, 2004), with the U.S. withdrawal from the Kyoto Protocol in 2001 as one of the most visible moves.

In this context, a particularly unnerving development for the Gulf Coast is the recent finding that hurricane destructiveness (i.e., intensity and duration) may have increased over the past decades, exhibiting a pattern coherent with changes in sea-surface temperatures in the North Atlantic and North Pacific (Emanuel, 2005). These results are echoed by an analysis of low-latitude oceans worldwide (Webster et al., 2005), showing an increase in Category 4 and 5 hurricanes over the past 35 years. Such observations warrant serious concern given rising sea-surface temperatures due to global warming (Barnett et al., 2005), although there is vigorous debate on the connection between climate change and powerful tropical cyclones (e.g., Landsea et al., 2006).

The Katrina disaster might have the potential of reaching far beyond the U.S. Gulf Coast and its vulnerability to coastal hazard. The unfortunate notion that the lack of response to repeated warnings by scientists contributed to this immensely costly catastrophe could, perhaps, have a positive side-effect. In this context, Hurricane Katrina could be viewed as a metaphor for the much larger problem of global warming (cf. Tidwell, 2006). In a strikingly similar fashion, the U.S. federal government has chosen to largely ignore the call for action on this front, notably the need to curb the emission of greenhouse gases (e.g., King, 2004). The analogy between the global warming challenge and Katrina is striking: a substantial, preemptive, and feasible investment in a broad spectrum of science-based mitigation efforts is likely to be highly costeffective in the longer term. As always, long-term decisions tend not to fare well in political systems dictated by four-year election cycles, but the pressure on the U.S. government to take action with regard to climate change is mounting.

Regardless, Ward Koster can pride himself in having played a significant role in directing our science into the vital area of the impact of global warming on Earth surface processes - a field that is likely to feature prominently on the scientific agenda for many years to come. Undoubtedly, many of his students will continue to make significant contributions to this broad area of research.

\section{Acknowledgements}

The first draft of this paper was written during an unplanned sabbatical leave at the University of Texas at Arlington (Department of Earth and Environmental Sciences) and the University of Chicago (Department of the Geophysical Sciences) during the fall of 2005. I am particularly indebted to John Holbrook and Doug MacAyeal for their unconditional hospitality. I also would like to express my gratitude to their respective institutions for accommodating myself as well as a considerable share of the displaced academic community from New Orleans. This paper benefited greatly from field trips to key localities in the New Orleans area led by Steve Nelson, as well as his insights about levee failures. Reviews by Whitney Autin and an anonymous referee allowed me to improve the paper, although the opinions expressed herein are strictly my own. Last but not least, I would like to express my gratitude to Ward Koster for his stimulating and supportive leadership during a critical phase of my scientific career.

\section{References}

Barnett, T.P., Pierce, D.W., AchutaRao, K.M., Gleckler, P.J., Santer, B.D., Gregory, J.M. \& Washington, W.M., 2005. Penetration of human-induced warming into the world's oceans. Science 309: 284-287.

Boer, M.M., Koster, E.A. \& Lundberg, H., 1990. Greenhouse impact in Fennoscandia - Preliminary findings of a European workshop on the effects of climatic change. Ambio 19: 2-10.

Bourne, J., 2000. Louisiana's vanishing wetlands: Going, going ... Science 289: 1860-1863.

Britsch, L.D. \& Dunbar, J.B., 1993. Land loss rates: Louisiana Coastal Plain. Journal of Coastal Research 9: 324-338.

Costanza, R., D'Arge, R., De Groot, R., Farber, S., Grasso, M., Hannon, B., Limburg, K., Naeem, S., O'Neill, R.V., Paruelo, J., Raskin, R.G., Sutton, P. \& Van den Belt, M., 1997. The value of the world's ecosystem services and nature capital. Nature 387: 253-260.

Day, J.W., Jr. \& Templet, P.H., 1989. Consequences of sea level rise: Implications from the Mississippi Delta. Coastal Management 17: 241-257.

Day, J.W., Jr., Boesch, D.F., Clairain, E.J., Kemp, G.P., Laska, S.B., Mitsch, W.J., Orth, K., Mashriqui, H., Reed, D.J., Shabman, L., Simenstad, C.A., Streever, B.J., Twilley, R.R., Watson, C.C., Wells, J.T. \& Whigham, D.F., 2007. Restoration of the Mississippi Delta: Lessons from Hurricanes Katrina and Rita. Science 315: 1679-1684.

Dixon, T.H., Amelung, F., Ferretti, A., Novali, F., Rocca, F., Dokka, R., Sella, G., Kim, S.-W., Wdowinski, S. \& Whitman, D., 2006. Subsidence and flooding in New Orleans. Nature 441: 587-588.

Donnelly, J.P., Cleary, P., Newby, P. \& Ettinger, R., 2004. Coupling instrumental and geological records of sea-level change: Evidence from southern New England of an increase in the rate of sea-level rise in the late 19th century. Geophysical Research Letters 31: L05203, doi: 10.1029/2003GL018933.

Emanuel, K., 2005. Increasing destructiveness of tropical cyclones over the past 30 years. Nature 436: 686-688. 
Fischetti, M., 2001. Drowning New Orleans. Scientific American 285 (4): 76-85. Fisk, H.N. \& McFarlan, E., Jr., 1955. Late Quaternary deltaic deposits of the Mississippi River. In: Poldervaart, A. (ed.): Crust of the earth. Geological Society of America Special Paper 62: 279-302.

Gagliano, S.M., Meyer-Arendt, K.J. \& Wicker, K.M., 1981. Land loss in the Mississippi River Deltaic Plain. Gulf Coast Association of Geological Societies Transactions 31: 295-300.

Gehrels, W.R., Kirby, J.R., Prokoph, A., Newnham, R.M., Achterberg, E.P., Evans, H., Black, S. \& Scott, D.B., 2005. Onset of recent rapid sea-level rise in the western Atlantic 0cean. Quaternary Science Reviews 24: 2083-2100.

Gerritsen, H., 2005. What happened in 1953? The Big Flood in the Netherlands in retrospect. Philosophical Transactions of the Royal Society A363: 1271-1291.

González, J.L. \& Törnqvist, T.E., 2006. Coastal Louisiana in crisis: Subsidence or sea level rise? Eos 87: 493, 498.

Groat, C., 2005. Hurricane Katrina and New Orleans: 'I told you so' is not enough. Eos 86: 341 .

Jelgersma, S., 1961. Holocene sea level changes in the Netherlands. Mededelingen van de Geologische Stichting, Serie C 6 (7): 1-100.

Jonkman, S.N., Stive, M.J.F. \& Vrijling, J.K., 2005. New Orleans is a lesson to the Dutch. Journal of Coastal Research 21 (6): xi-xii.

Kabat, P., Van Vierssen, W., Veraart, J., Vellinga, P. \& Aerts, J., 2005. Climate proofing the Netherlands. Nature 438: 283-284.

King, D.A., 2004. Climate change science: Adapt, mitigate, or ignore? Science 303: 176-177.

Koster, E.A., 1991. Assessment of climate change impact in high-latitudinal regions. Terra 103: 3-13.

Koster, E.A. \& Nieuwenhuijzen, M.E., 1992. Permafrost response to climatic change. In: Boer, M. \& Koster, E. (eds): Greenhouse-impact on cold-climate ecosystems and landscapes. Catena Supplement 22: 37-58.

Lambeck, K., Anzidei, M., Antonioli, F., Benini, A. \& Esposito, A., 2004. Sea level in Roman time in the Central Mediterranean and implications for recent change. Earth and Planetary Science Letters 224: 563-575.

Landsea, C.W., Harper, B.A., Hoarau, K. \& Knaff, J.A., 2006. Can we detect trends in extreme tropical cyclones? Science 313: 452-454.

Louisiana Coastal Wetlands Conservation and Restoration Task Force and the Wetlands Conservation and Restoration Authority, 1998. Coast 2050: Toward a sustainable coastal Louisiana. Louisiana Department of Natural Resources (Baton Rouge): 161 pp.

Meehl, G.A., Stocker, T.F., Collins, W.D., Friedlingstein, P., Gaye, A.T., Gregory, J.M., Kitoh, A., Knutti, R., Murphy, J.M., Noda, A., Raper, S.C.B., Watterson, I.G., Weaver, A.J. \& Zhao, Z.-C., 2007. Global climate projections. In: Solomon, S., Qin, D., Manning, M., Chen, Z., Marquis, M., Averyt, K.B., Tignor, M. \& Miller, H.L. (eds): Climate change 2007. The physical science basis. Cambridge University Press (Cambridge): 747-845.

Milne, G.A., Long, A.J. \& Bassett, S.E., 2005. Modelling Holocene relative sealevel observations from the Caribbean and South America. Quaternary Science Reviews 24: 1183-1202.

Mitrovica, J.X. \& Milne, G.A., 2002. On the origin of late Holocene sea-level highstands within equatorial ocean basins. Quaternary Science Reviews 21: 2179-2190.

Mooney, C., 2005. The Republican war on science. Basic Books (New York): 342 pp. Nelson, S.A. \& Leclair, S.F., 2006. Katrina's unique splay deposits in a New Orleans neighborhood. GSA Today 16 (9): 4-10.
Parry, M.L., Canziani, O.F., Palutikof, J.P., Van der Linden, P.J. \& Hanson, C.E. (eds), 2007. Climate change 2007. Impacts, adaptation and vulnerability. Cambridge University Press (Cambridge): 976 pp.

Peltier, W.R., 1998. Postglacial variations in the level of the sea: Implications for climate dynamics and solid-earth geophysics. Reviews of Geophysics 36: 603-689.

Penland, S. \& Suter, J.R., 1988. Barrier island erosion and protection in Louisiana: A coastal geomorphological perspective. Gulf Coast Association of Geological Societies Transactions 38: 331-342.

Reed, D.J. \& Wilson, L., 2004. Coast 2050: A new approach to restoration of Louisiana coastal wetlands. Physical Geography 25: 4-21.

Saucier, R.T., 1963. Recent geomorphic history of the Pontchartrain Basin. Louisiana State University Press (Baton Rouge): 114 pp.

Seed, R.B., Bea, R.G. et al., 2006. Investigation of the performance of the New Orleans flood protection systems in Hurricane Katrina on August 29, 2005. www.ce.berkeley.edu/ new_orleans/.

Stanley, D.J. \& Warne, A.G., 1993. Nile delta: Recent geological evolution and human impact. Science 260: 628-634.

Tidwell, M., 2006. The ravaging tide. Strange weather, future Katrinas, and the coming death of America's coastal cities. Free Press (New York): 196 pp.

Törnqvist, T.E., González, J.L., Newsom, L.A., Van der Borg, K. \& De Jong, A.F.M., 2002. Reconstructing 'background' rates of sea-level rise as a tool for forecasting coastal wetland loss, Mississippi Delta. Eos 83: 525, 530-531.

Törnqvist, T.E., González, J.L., Newsom, L.A., Van der Borg, K., De Jong, A.F.M. \& Kurnik, C.W., 2004. Deciphering Holocene sea-level history on the U.S. Gulf Coast: A high-resolution record from the Mississippi Delta. Geological Society of America Bulletin 116: 1026-1039.

Törnqvist, T.E., Bick, S.J., Van der Borg, K. \& De Jong, A.F.M., 2006. How stable is the Mississippi Delta? Geology 34: 697-700.

Toscano, M.A. \& Macintyre, I.G., 2003. Corrected western Atlantic sea-level curve for the last 11,000 years based on calibrated ${ }^{14} \mathrm{C}$ dates from Acropora palmata framework and intertidal mangrove peat. Coral Reefs 22: 257-270.

Van Beek, J.L. \& Meyer-Arendt, K.J., 1982. Louisiana's eroding coastline: Recommendations for protection. Louisiana Department of Natural Resources (Baton Rouge): 49 pp.

Van de Plassche, 0., 1982. Sea-level change and water-level movements in the Netherlands during the Holocene. Mededelingen Rijks Geologische Dienst 36: 1-93.

Van Heerden, I. \& Bryan, M., 2006. The storm. What went wrong and why during Hurricane Katrina - the inside story from one Louisiana scientist. Viking (New York): 308 pp.

Vrijling, J.K., 2001. Probabilistic design of water defense systems in the Netherlands. Reliability Engineering and System Safety 74: 337-344.

Webster, P.J., Holland, G.J., Curry, J.A. \& Chang, H.-R., 2005. Changes in tropical cyclone number, duration, and intensity in a warming environment. Science 309: 1844-1846. 